\title{
A Door Lintel with Cartouches at the Egyptian Museum(JE.59895)
}

\section{Dr. Bassem Mohamed Sayed Ahmed ${ }^{\bullet}$}

\section{Abstract:}

This paper deals with a New Kingdom limestone door lintel from Medinet Habu, which is currently housed in the Cairo Museum. It bears three royal names of three kings of the New Kingdom; Amenophis I, Thutmosis IV and Ramsses II, who were worshiped as local deities at Deir El-Medina because of their roles in establishing and developing the Valley of the Kings and the society of artists and workers at Deir El-Medina. There is no owner's name on this door lintel, but from the royal names we can assume that it was made after the reign of Ramses II. By referring to the title of Hathor, which appears on this door lintel and was also found on the statue of Amom-Mes from the $20^{\text {th }}$ Dynasty, the location of the name of King Ramses II from $19^{\text {th }}$ Dynasty between the names of two of $18^{\text {th }}$ Dynasty kings indicates the distinctive status of Ramses II, which was either made during his reign or in the era of his predecessors of the $20^{\text {th }}$ Dynasty. Thus, it is likely that this door lintel dates back to the $20^{\text {th }}$ Dynasty.

\section{Key words:}

Lintel - Door - Amenhotep I - Thutmose IV - Ramses II Medinet Habu - Deir el- Medina - The New Kingdom - The $20^{\text {th }}$ Dynasty

\footnotetext{
- Assistant Prof. of Egyptology, Archaeology Department, Faculty of Arts, Ain Shams University - Egypt and Taif Universty - KSA. bassemyossef65@gmail.com
} 


\section{1- Description:}

This limestone door lintel came from Medinet Habu and is currently housed in the Cairo Museum ${ }^{(1)}$.The dimensions of this door lintel are $60 \mathrm{~cm} \times 21 \mathrm{~cm}$. It was probably reused in later periods, as evidenced by the reliefs that were found in the same area at Medinet Habu. ${ }^{(2)}$ It is broken in its upper right side. The upper part is shaped in the form of the Egyptian cornice. A winged sun disk could be seen in the center with two cobras. The word $b h d t$ is written on both sides referring to Horus Behdite.

Under the cornice, written from left to right, is the formula of $\left\langle h t p>\right.$ di $n s w$, followed by the phrase mry-Imn-R $R^{c} n b n s w t-$ $t 3 w y^{(3)}$ and the names of the kings Amenophis I, Ramses II and Tuthmosis IV, while on the right there is the title mry-hwt-hr $h m t(m) W 3 s t^{(4)}$. The lower part of the lintel is divided into three sections and there is a guideline at the end of each section, which can be clearly seen on both sides of the lower part. Both the hieroglyphs and the inscription are rendered in sunken relief.

This limestone door lintel most likely dates back to $20^{\text {th }}$ Dynasty and it is clear that there were attempts to erase some of its inscriptions, perhaps during the Greco-Roman period, when it had been reused. This is evidenced by the architectural remnants found with it in the same location. ${ }^{(5)}$

* Bassem Mohamed Sayed Ahmed, Assistant Prof. of Egyptology, Archaeology Department, Faculty of Arts, Ain Shams University - Egypt and Taif Universty - KSA.

- I would like to express my appreciation to Prof. Hassan Selim, for his scientific advice on this article, and to Associate Prof. Ashraf Fathy and Associate Prof. Ali Abd El-Halim for their scientific review to this article and to and Mrs. Sabah Abdelrazik, Chief Director of Egyptian Muesum for allowing me to publish this object .

(1) PM. 12,776

(2) Ibid, 776-777.

(3) Leitz, C.LGG,I,320

(4) Ibid, V,80

${ }^{(5)}$ For more details, see: Holscher,U. The Excavation of Medinet Habu, The University of Chicago press, $1927-1933$ 


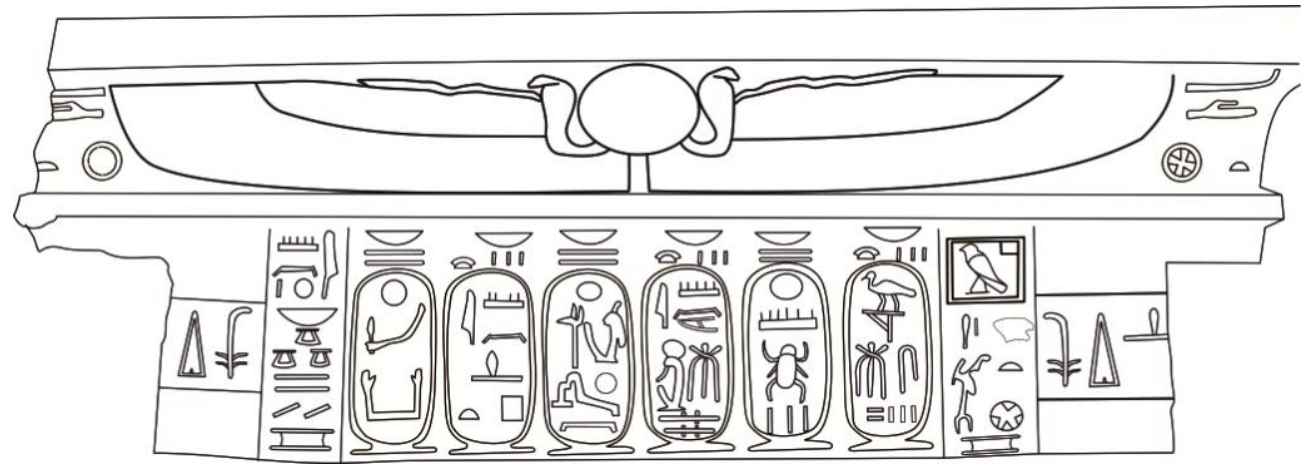

Fig.1 (line drawing for the door lintel by the researcher)

\section{2- Text Study:}

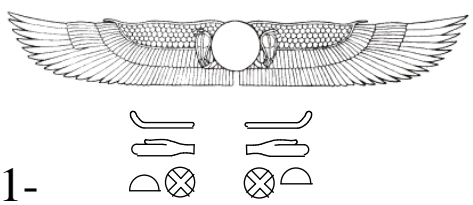

$$
B h d t^{(6)} \quad B h d t^{(7)}
$$

Horus Behdite Horus Behdite

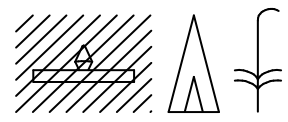

htp di $n s w$

An $<$ offering $>$ given by the king

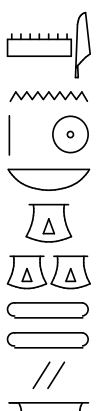

3-I

Mry Imn-r'-nb nswt-t3wy

\footnotetext{
${ }^{(6)}$ Wb. I, 470.6-8; Otto,E. Behedeti, in: LÄ I.4, 683.

${ }^{(7)}$ Wb. I, 470.6-8; Otto, E. Behedeti, in: LÄ I.4, 683.
} 
Beloved of Amon-Re, lord of the thrones of the two lands ${ }^{(8)}$

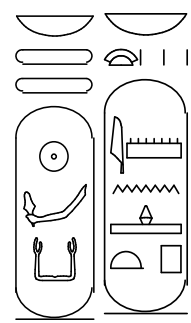

4-Nb-t3wy $\underline{d} s r k 3-r^{\top} n b-h^{\complement} w$ Imn hִtp

Lord of the two lands, Zeserkare ${ }^{(9)}$,lord of coronation Amenophis I

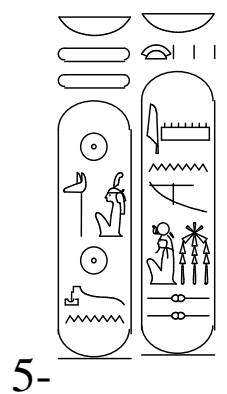

Nb-t3wy wsr m3`t $R^{\complement}$ stp $n R^{\complement} n b h^{\complement} w R^{\complement}$ mss mri Imn

Lord of the two lands,Weser Maat-Re Setep en Re, lord of coronation, Ramsses II beloved of Amon.

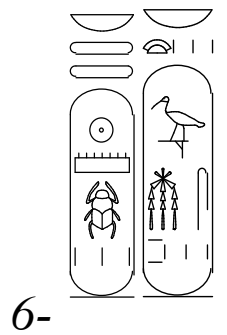

Nb- t3wy mn hprw- $R^{\top} n b-h^{\top} w \underline{D} h w t i-m s w$

Lord of the two lands, Men khepro-Re, lord of coronation, Thutmosis IV.

\footnotetext{
${ }^{(8)}$ Wb. II, 322.10; Leitz, C. LGG I, 321.

${ }^{(9)}$ Wb. III, 242.1-2 ; Leitz, C. LGG III, 712.
} 

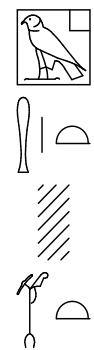

7-

Mry hmt ḥwt-ḥr ${ }^{(10)} m W 3 s t^{(11)}$

Beloved of the majesty of Hathor at Thebes.

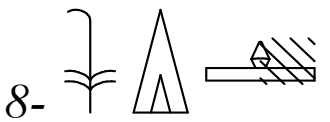

htp di-nsw

Offering given by the king.

\section{3- Comment:}

${ }^{\mathrm{a}-}$ The upper part of the winged sun disk, which is at the center of the lintel, is engraved in raised relief, while the word $B h d t$, is written symmetrically on both sides of it in sunken relief. Both the name bhdt and the formula htp di $n s w$ is written at both sides of the lintel symmetrically.

b-The word Bhdt is written in two opposite directions, which refers to the protection of the god Horus, who was represented as the winged sun disk. ${ }^{(12)}$

c- The whole text is written in simple, detail-free writing. ${ }^{(13)}$

d- The formula htp di nsw on each side lacks its complement, which was likely written on the door jamb.

(10) Wb,III,92;http://aaew.bbaw.de; Leitz, C. LGG,V,80,146.

${ }^{(11)}$ De Meulenaere, De Strooper, CdE 73, no.146(1998) 244-260

${ }^{(12)}$ Wb,I,470; http://aaew.bbaw.de; LGG,II,814. Leitz, C. LGG,V,80,146.

(13) Fischer, H.G. Hieroglyphen, in: LÄ II, 1189-1199, Loprieno,A. Ancient Egyptian, A Linguistic Introduction, Cambridge University Press, 1996, 20-22. 
${ }^{\mathrm{e}}$ The title of Imn-Re $n b$ nswt $t 3 w y$ is one of Amon titles that appears at Karnack in the $18^{\text {th }}$ Dynasty and on a block statue from the $20^{\text {th }}$ Dynasty after the formula htp di $n s w .{ }^{(14)}$

${ }^{\mathrm{f}}$-The word htp in the formula htp di $n s w$ was not written on the left side before the name of 'Imn-R', while on the right side it was written as a thin line ${ }^{(15)}$ lacking part of the glyph before the name of $h w t-h r$.

g- The title hmt hwt-hr $(m)$ W3st was a title of $h w t-h r$ that appeared with the htp di $n s w$ formula in the $20^{\text {th }}$ Dynasty, $h w t-h r$ $m W 3 s t$ with the preposition $m^{(16)}$. There was also a title, hmt ntr $h w t$ - $h r$, which was widely used for the priestess of Hathor from the Old Kingdom ${ }^{(17)}$.

This title $h m t h w t-h r(m) W 3 s t$ is often used as one of the main titles of the goddess Hathor at Thebes, as it appears in the $20^{\text {th }}$ Dynasty in htp di $n s w$ formula with the adjective hmt. In this case, it means 'majesty', especially when this title is followed by htp di nsw.

\section{4- Conclusion:}

This limestone door lintel came from Medinet Habuatat Thebes. It bears three royal names of three kings of the New Kingdom; Amenophis I, Thutmosis IV and Ramsses II, who were worshiped as local deities at Deir El-Medina because of their roles in the founding and development of the Valley of the Kings and the society of artists and workers at Deir El-Medina ${ }^{(18)}$. There is no owner's name on this door lintel, but from the royal names

\footnotetext{
${ }^{(14)}$ De Meulenaere, De Strooper, op.cit. 244-260.

${ }^{(15)}$ Smither,P.C., Writing of htp-di-nsw in the Middle and New Kingdom, in JEA25(1939):34-37. Ilin-Tomich, A., Changes in the htp-di-nsw Formula in the Late Middle Kingdom and the Second Intermediate Period, in: ZAS138(2011): 20-34.

${ }^{(16)}$ Ibid. 244-260; Leitz, C., LGG, V, 80

${ }^{(17)}$ Ranke, H, Die Personennamen I, Glückstadt 1935,392.2. http://aaew.bbaw.de; Wb 3, 90.10.hm.t-ntr-hw.t-hr.w,

${ }^{(18)}$ Hornung,E. A meophis I, in: LÄ,I-2, 201-203; Redford, D.B., The Oxford Encyclopedia of Ancient Egypt, Oxford, 2001,vol. I, 71,403-405,vol.III,118, Černy, J.A. Community of the Workmen at Thebes in the Ramesside Period,IFAO,1973, 182ff.
} 
we can assume that it was made after the reign of the Ramses II. By referring to the title of Hathor, which appears on this door lintel and was also found on the statue of Imn- $m s$ from the $20^{\text {th }}$ Dynasty $^{(19)}$,the location of the name of King Ramses II from $19^{\text {th }}$ Dynasty between the names of two of $18^{\text {th }}$ Dynasty kings indicates the distinctive status Ramses II, which was either made during his reign or in the era of his predecessors of the $20^{\text {th }}$ dynasty. Thus, it is likely that this door lintel dates back to the $20^{\text {th }}$ Dynasty.

${ }^{(19)}$ Leitz, C. LGG,V,80; De Meulenaere, DeStrooper, CdE 73, no.146(1998) 244-260 


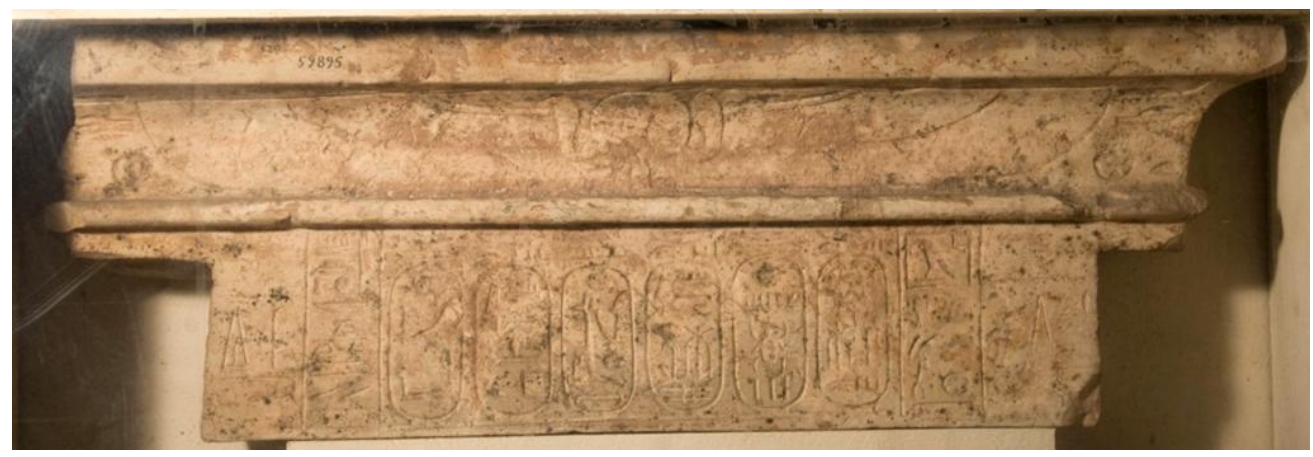

An Inscribed Door Lintel from Medinet Habu

(JE.59895) (Photographed by the researcher)

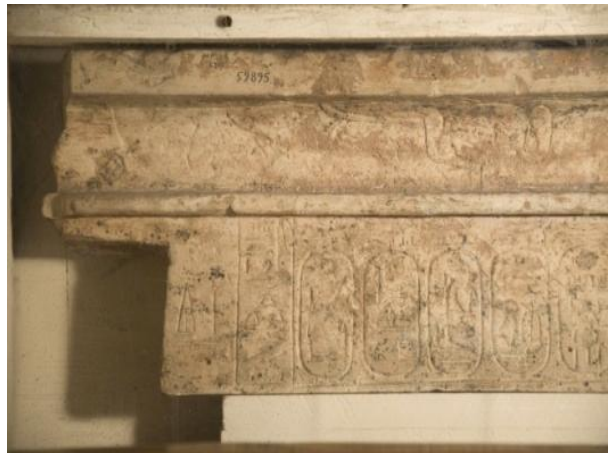

(JE.59895)

The left side

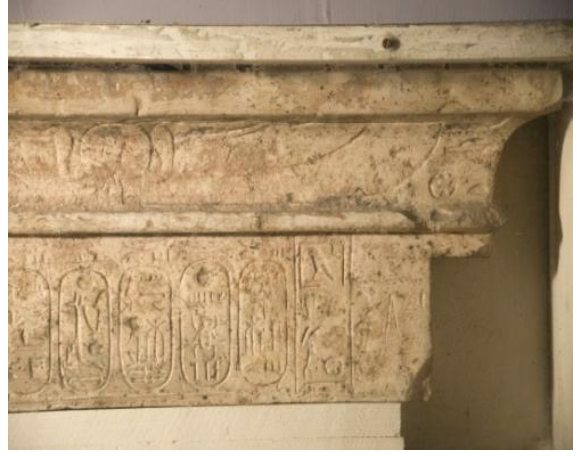

(JE.59895)

The right side

(Photographed by the researcher) 


\section{Bibliography:}

-De Meulenaere, De Strooper, CdE 73, no.146(1998) 244-260.

-Černy, J.A. Community of the Workmen at Thebes in the Ramesside Period,IFAO,1973, 182ff.

- Erman, A. Grapow, H.Worter Bouch Egyptischen Sprache, Berlin, 1971

-Fischer, H.G. Hieroglyphen, in: LÄ II, 1189-1199

- Holscher,U. The Excavation of Medinet Habu, The University of Chicago press, 1927-1933

-Hornung,E. A meophis I, in: LÄ,I-2, 201-203http://aaew.bbaw.de; Wb 3, 90.10.Hm.t-nTr-Hw.t-Hr.w

- Ilin-Tomich, A., Changes in the Htp-di-nsw Formula in the Late Middle Kingdom and the Second Intermediate Period, in: ZAS138(2011): 20-34.

-Leitz, CH. Lexikon der Ägyptischen Götter Und Götterbezeichnungen, Band III, Paris 2002

-Loprieno,A. Ancient Egyptian, A Linguistic Introduction, Cambridge University Press, 1996

-Porter, B.\& Moss R. Topographical Bibliography of Ancient Egyptian Hieroglyphic Texts, Reliefs and Paintings, Oxford,1999

- Ranke,H. Die Ägyptischen Personennamen, Band I,Cluckstadt,1935

-Redford, D.B., The Oxford Encyclopedia of Ancient Egypt, Oxford, 2001,vol. I

-Smither,P.C., Writing of Htp-di-nsw in the Middle and New Kingdom, in JEA25(1939):34-37

- Wb,III,92;http://aaew.bbaw.de; 


\section{عتب باب عليه خراطيش بالمتحف المصري}

\section{(JE.59895)}

\section{•باسم محمد سيد أحمد}

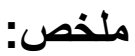

يتتاول هذا البحث نشر علمي ودراسة لعتب باب من الحجر الجيري من الدولة

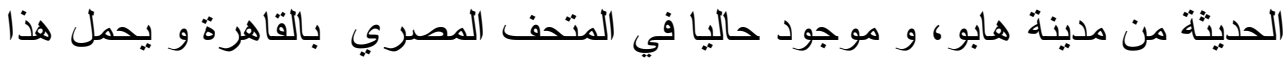
العتب ثلاثة أسماء ملكية لثلاثة من ملوك الدوائة الدولة الحديثة وهم أمنحتب الأول وتحوتمس الر ابع ورمسيس الثاني و الذين كانو ا يُعبدون كآلهة محلية في دير التئة الكدينة

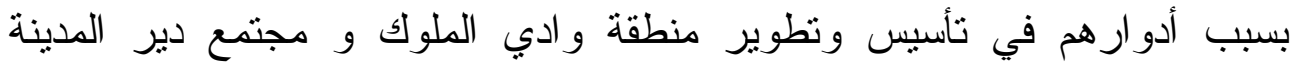

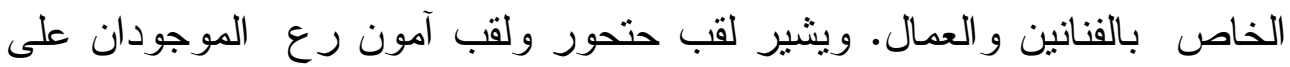
هذا العتب و بمقارنته بنفس الألقاب لهذين المعبودين الموجودة على لفئ تمثال أمون

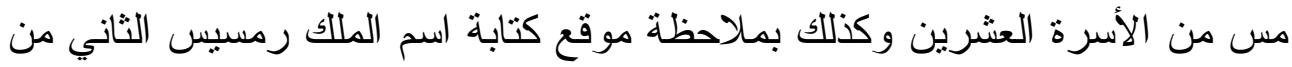
الأسرة التاسعة عشرة ووجوده متوسطا لاسمين لملكين من الأسرة الثامنة عشرة

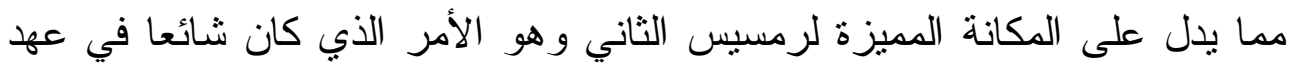

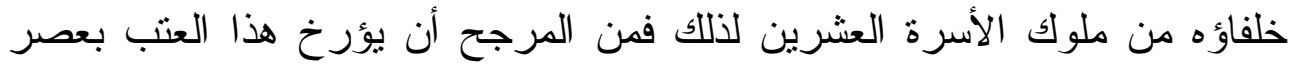

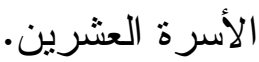

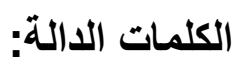

عبر المدينة- الدولة الحديثة- الأسرة - تحوتمس الر ابع - رمسيس الثاني - مدينة هابو -

• مدرس الآثار المصرية بقسم الآثار - كلية الآداب - جامعة عين شمس وقسم التاريخ بكلية

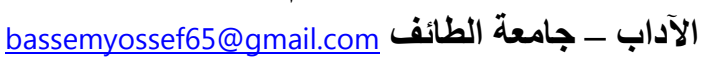

